\title{
When deserts flood: risk management and climatic processes among East African pastoralists
}

\author{
Peter D. Little ${ }^{1, *}$, Hussein Mahmoud ${ }^{1,2}$, D. Layne Coppock ${ }^{3}$ \\ ${ }^{1}$ Department of Anthropology, University of Kentucky, Lexington, Kentucky 40506-0024, USA \\ ${ }^{2}$ Department of Geography, Egerton University, PO Box 536, Njoro, Kenya \\ ${ }^{3}$ Department of Rangeland Resources, Utah State University, Logan, Utah 84322-5230, USA
}

\begin{abstract}
Pastoral populations of East Africa confront multiple risks associated with drought, food shortages and insecurity. In this arid region, drought is a 'normal' event and herders pursue strategies of mobility, livestock loaning and diversification to combat its effects. What is not a norm are prolonged floods when precipitation cycles become inverted and dry season rainfall greatly exceeds the average amount for a year. This article examines the events and responses to 'El Niño' in the rangeland areas of northern Kenya and southern Somalia during 1997/98. It suggests that these global climatic episodes need to be assessed against local factors and processes, which strongly shape their impacts on human populations.
\end{abstract}

KEY WORDS: African pastoralism $\cdot$ Drought $\cdot$ Floods $\cdot$ Political ecology $\cdot$ Food security $\cdot$ Development policy

\section{INTRODUCTION}

Climatic risks are the norm in the dry pastoral areas of East Africa and often account for widespread social and economic costs and human suffering. Nowhere is this more apparent than in northern Kenya and southern Somalia, which in 2000 were once again caught in the throes of a terrible 'natural' disaster. Drought-or at least local perceptions of it - and associated crashes ('busts') in livestock herds and food availability occurred at intervals of about every 4 years during the past 2 decades. Regional droughts took place in 1979/80, 1984, 1987/88, 1991/92, 1996/97 and 1999/ 2000, with the most severe taking place in 1979/80, 1984 and, most recently, 1999/2000. In the past decade alone these drought events are said to have become more frequent and punctuated by occasional periods of excessive rainfall that devastate local and regional economies. The most severe of these non-drought events, the so-called El Niño rains of 1997/98, occur much less frequently in the area, but when they come their impact can be equally severe. In the past $40 \mathrm{yr}$

*E-mail: pdlitt1@pop.uky.edu they have seriously affected the region during only 1 other year, 1961. Consequently, many herders who have key decision-making roles were young or not yet born at the time of the earlier disaster and, thus, unfamiliar with its consequences.

The El Niño floods of 1997/98 and the increased acknowledgement of drought during the 1980s and 1990s has raised Kenya's national awareness of global climatic processes. These events also have graphically portrayed the devastating social and economic effects of abrupt climatic changes, some of which are discussed below. However, the treatment of these global episodes needs to be assessed in light of local factors and processes, which strongly shape their impact and even perceptions of their very existence. In short, these extreme climatic events are not just environmental occurrences devoid of social and cultural contexts. For example, analyses of $>30 \mathrm{yr}$ of rainfall data from an arid district of northern Kenya, Marsabit, indicate no significant changes in rainfall patterns (Mahmoud 1996), even though local and regional perceptions point to greater frequency of drought than in the past. What accounts for the discrepancy? The contradiction exposes the fact that unlike climatic notions of 
'drought,' local definitions take into account variables other than rainfall. Drought in northern Kenya is defined in terms of vegetation cover and livestock condition (including deaths), both of which are influenced by land use patterns and animal stocking rates, in addition to rainfall (Little 1992a). One task of the social scientist, therefore, is to reconcile global climatic processes and their definitions with 'ground level' observations of their impact and the ways in which they interact with local and regional factors.

On the 'ground' the choices governing herder decisions in East Africa encompass a multitude of factors, but generally cluster around issues of climate, animal disease, insecurity and access to markets. Common strategies to confront these constraints entail mobility and the maintenance of resource access to both grazing and water. Without these essential components a herder is extremely limited in responding to drought and other catastrophes, such as excessive rainfall. Indeed, a case can be made that just the single factor of mobility explains why certain herding groups fare relatively well during extreme climatic variation, while others do not. ${ }^{1}$

This article addresses the risks associated with each of the above elements through an examination of herder decision-making in the Somali border areas of Garissa District, Kenya, and the Lower Jubba Region, Somalia, and in Marsabit and Moyale districts, northern Kenya. Data for the analysis were collected under 4 different research projects of the authors: a study of Somali herder households and marketing from 1986 to 1988 (Little: Little 1992b, 1994, 1996c); a study of the causes of land degradation in Marsabit and Moyale districts in 1995 (Mahmoud: Mahmoud 1996); a study of regional and cross-border livestock trade in the summers of 1995, 1996 and 1998 (Little \& Mahmoud: Little 1996b, in press b); and a project on Pastoral Risk Management in East Africa (PARIMA) under the Global Livestock Collaborative Research Support Program (GL-CRSP) (Coppock, Little and Mahmoud: Mahmoud \& Little 2000, Little et al. 2001). The latter project addresses pastoral risk management and has allowed the authors to revisit existing data and to collect additional information on the ways in which climatic volatility affects local perceptions of risk. The paper suggests that risks associated with climatic variability in the region relate closely to elements of inse-

\footnotetext{
${ }^{1}$ Preliminary results from the Pastoral Risk Management in East Africa (PARIMA) project show that areas of Marsabit where herd mobility is widespread fared much better during the drought of 2000, in terms of livestock losses, than areas such as Baringo District, where movement is constrained (J. McPeak pers. comm., McPeak 2000)
}

curity (and conflict), market instability and animal disease. They are all integrally related in the rangelands of East Africa. The perception of frequent droughts and macro-climatic changes show the interrelations among these variables, as does the less frequent event of floods such as the recent El Niño disaster. The presence of multiple risks and of economic pressures that restrict herder mobility aggravate the effects of climatic variability and leave pastoralists to assume that long-term changes in rainfall patterns have occurred. The findings in the paper are preliminary, and intensive data gathering under the GL-CRSP project on pastoral risk management is just now (2000/01) beginning (see footnote 1; Little et al. 2001).

The article is divided into 4 parts. The first part discusses a general framework for addressing how climate, insecurity, market and animal disease risks are integrated. The case of the 1997/98 El Niño floods is used to illustrate the model. In the second and third parts of the paper case studies from the Somalia borderlands and Marsabit and Moyale districts, Kenya are summarized to show how climate and other risks affect different pastoral systems. In the case study from Moyale and Marsabit, climatic variability is shown to be a major risk, but insecurity and market volatility exaggerate its effects. Preliminary assessment of the situation in the Kenyan districts indicates that the lack of viable markets coupled with insecurity poses a major problem in pastoral risk management strategies (Smith et al. 1999, Little et al. 2001). The data presented in this article address the various risks and losses associated with the El Niño floods of 1997/98. The example from southern Somalia clearly shows that local herders have generally fared better during recent climatic disasters than have neighboring groups from northern Kenya. While persistent armed conflict affects herd movements in the region, unlike many Kenyan herders, Somali pastoralists have been able to maintain risk management strategies of mobility and access to key resources (Little 1996a). The final section of the paper summarizes the main points and discusses their implications for social science research and policy.

\section{FRAMEWORK FOR ADDRESSING PASTORAL RISKS}

Northern Kenya and southern Somalia provide unique opportunities to address herder decision making under conditions of extreme risk and to assess the ways in which global climatic episodes affect local economies. Climatic instability and political insecurity are normal parameters in the areas, as they are in most semi-arid areas of East Africa, but the situation is par- 
ticularly attenuated in the 2 study regions. Additionally there are well-documented animal disease vectors in parts of both sites, which increase production risks for herders. While considerable attention in the literature has been given to herd management strategies under conditions of drought (McCabe 1987, 1994), very few works have addressed the interplay of livestock disease, climate and conflict, and their effect on herder decisions (Little 1996a). This gap exists even though during periods of prolonged low rainfall, disease and insecurity (and market collapse) often cause greater losses of cattle and small stock than drought itself.

Access to markets also figures prominently in herders' decisions about where and when to move livestock during the year. Markets have increased in importance during the past 2 decades, but access to them was severely disrupted by the floods of 1997/98. At the onset of a drought a herder who assumes the worse - that climatic and livestock conditions will continue to deteriorate-may unload animals at the market, often at severely reduced prices. Since herders are very dependent on grain consumption during dry seasons and droughts, they must deal with the market even when conditions are unfavorable. Distance to livestock and cereal markets, as well as the terms of trade between livestock and grain prices, influence herders' migrations. The latter variable measures the relations between the price herders receive for their product (livestock) and what they have to pay for their main import item, grain. In northern Kenya increased dependence on markets and food aid has resulted in excessive population densities around market towns, which has altered grazing patterns and led to localized environmental degradation (Little in press b). These factors reduce herder mobility and, thus, their capacity to respond to climatic variability.

A pastoralist of northern Kenya or southern Somalia, therefore, confronts a nested hierarchy of risks at any give time during the year, the importance of which varies depending on the circumstances. During certain times, drought may be the overriding risk while at other times it may be animal disease or another constraint. The issue of risk needs to be addressed over 1 or more drought cycles (each of which covers from 5 to $7 \mathrm{yr}$ in the region). Climate, however, generally defines the annual cycle of herd and population movements, and the inter-annual cycles of drought (bust) and good (boom) years. The different elements of risk are closely monitored by herders, and elaborate social networks based on kin, ethnicity, age and other principles are maintained to gather and disseminate information about risk. Herders are well aware of the tough decisions that have to be made in certain years. For example, at the peak of 1 of Kenya's worst droughts in this century, the disaster of 1984, a wizened elderly herder of Baringo District, Kenya lamented to 1 of the coauthors (Little) that he should have transferred his animals to highland grazing early on in the drought. He was sure that they would die because of weakness if they were moved later in the drought, and acknowledged that he had made a mistake. He shrugged and exclaimed: 'What can I do ... If I decide not to move them but later choose to do so, they may be too weak to make the trek to the hills'.

The localized drought of 1996 in the Somalia borderlands also reveals the difficult choices that are made in an environment of multiple risks. In this case, rainfall and good pasture were concentrated in an area where clan-based conflict was endemic and risks of the livestock disease 'trypanosomiasis' were high. The herds were eventually moved to the insecure zone after numerous rounds of negotiation, but only after local cattle began to die (Little 1996a).

Despite conditions of instability and violence, herders still must make crucial decisions about where and when to move their animals during dry years. Rainfall is not affected by the presence of AK-47s. Pastoralists know the locations of political instability/conflict and chronic livestock diseases, but under stress conditions often have little choice but to use them. They also know of areas that are poorly served by markets and where access to grain and markets to sell livestock may be problematic at certain times of the year. With the endemic presence of livestock diseases, particularly trypanosomiasis and East Coast fever, and with increased political uncertainty, herders throughout East Africa face similar scenarios.

These types of risks are known to the herder and are addressed in daily practice. At another level are external risks that they may know of but over which they have little control or capacity to respond. In the case of market risks or El Niño floods, the herders may not be aware of the extent of risk, nor of the types of behavioral responses that are required. For example, the El Niño floods of 1997/98 destroyed market and transport infrastructure, which discouraged trader activity, broke market links and increased herders' vulnerability to food shortages - even though water and pasture availability were not problems after initial flooding. The risks associated with animal diseases were well known locally, but as will be discussed below, their impact on livestock marketing activities and consequently herder welfare were not adequately understood. In addition, uncommon livestock diseases (e.g. Rift Valley disease [RVD]) became a serious problem and few herders were able to correctly diagnose or treat the problem.

Fig. 1 shows the known as well as the less known risks in pastoral areas of East Africa. Herders of north- 


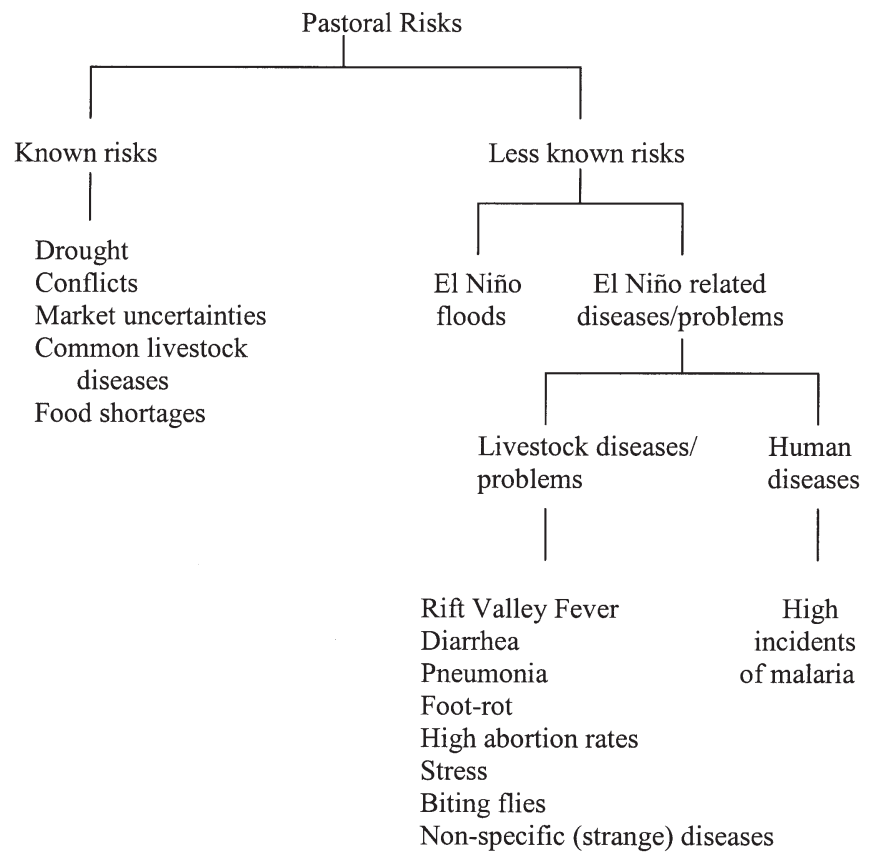

Fig. 1. Schema of pastoral risks

ern Kenya have mechanisms to deal with known risks, but they have little knowledge, if any, about how to cope with less known risks, such as an El Niño event. We would argue that the El Niño floods were a risk that caught herders off guard, and unlike droughts, were initially without proven coping mechanisms. Later on some herders realized that lengthy migrations, which are common in severe droughts, helped to ameliorate their effects. In 1997/98 the most productive pasture zones - river basins and lowland areas - and the lowland towns experienced excessive flooding. As with droughts, however, poorer herders with limited mobility were most affected by the floods, and many lost more than $50 \%$ of their flocks and herds.

While regional and local droughts are common features of East African rangelands, excessive rainfall and floods emerged as recent problems only during the past few years. Beginning in October 1997 unusually excessive rainfall occurred in the region's short rainy season and continued well into January, often one of the driest months of the year. In some places rainfall is estimated to have been as much as 10 to 20 times higher than normal monthly averages (UNIRIN $1997^{2}$, Clark 1998, p. 2). In southern Somalia these floods reached key wet season grazing zones well away from the Jubba River, inundating more than $800 \mathrm{~km}^{2}$ of rangelands and creating a continuous sheet of water across large expanses of the rangelands. The floods of 1997/98 completely al-

\footnotetext{
${ }^{2}$ United Nations Integrated Regional Information Network: www.irinnews.org
}

tered seasonal grazing patterns, covered wet season grazing areas and turned some dry season pastures unusable, and destroyed thousands of small stock, cattle and camels. The floods of 1997/98 transformed the areas in southern Somalia between the Jubba River and adjoining seasonal stream into 1 large lake (Fig. 2). On the Kenyan side the Tana River overflowed its banks and covered much of the key agricultural and pastoral zones of Garissa District. Some 120000 herders and farmers were displaced in Garissa and Mandera districts (UNIRIN 1997, see footnote 2).

What were the losses and destruction from this event in the Somalia borderlands? Because of the destruction of roads and other infrastructure, and the imposition of quarantines due to the presence of RVD, a disease spread by mosquitoes and associated with excessive flooding, the important cross-border livestock trade between Somalia and Kenya virtually ceased between November 1997 and February 1998. This restriction caused losses in market sales of about 20000 cattle, or the equivalent of about US\$3 million in value. More dramatic was the imposition by Saudi Arabia of a 12month ban due to RVD on all live animals imported to its country, which was about 1.3 million small stock, camels and cattle in 1996. This punitive action reduced the annual incomes of Somaliland's pastoralists and traders by more than $\$ 20$ million and regional state revenues by about $45 \%$ (Menkhaus \& Marcal 1998, Steffen et al. 1998). Once again, the spread of RVD was directly linked to the El Niño floods, and although its duration was very short term (less than a few months) its early presence kept Saudi Arabia from lifting its ban for several months. 'This decision [to ban the importation of live animals] was made in response to fears that animals from the eastern Horn of Africa carried Rift Valley fever, a vector-borne (mosquito) disease' (Menkhaus \& Marcal 1998, p. 37).

In terms of actual human and herd losses in the Somalia borderlands related to the recent floods and outbreak of diseases (RVD, but also foot rot and mange and caprine and bovine contagious pleuropneumonia; Anon. 1998, p. 261), more than 2000 human deaths (Lovgren 1997, p. 53) and up to $70 \%$ of small stock and 20 to $30 \%$ of cattle herds are estimated to have been lost (Clark 1998, p. 2). Over 60000 hectares of crop lands and the bulk of the agricultural crop of 1997 was lost in the Lower Jubba Region, which resulted in grain price increases of more than $600 \%$ in pastoral markets such as Afmadow, Somalia. Table 1 lists the prices of certain products at the Afmadow market, showing how much grain and milk prices increased between October 1997 and January 1998 and livestock prices declined between October 1997 and April 1998. Because of the floods, there were virtually no sales of livestock in January 1998 and thus no prices to record. Food prices fell consider- 
ably in March and April 1998 after food aid reached the flooded areas. Livestock prices remained relatively low until around June and July of that year.

Coupled with the loss in grain production was an almost complete destruction of transport links in many of the most seriously affected zones during November 1997 to February 1998. Thus, local shortages could not be supplemented by imports or food aid, which in the latter case had to be airlifted to parts of northern Kenya and southern Somalia. While access was better on the Kenyan side, grain prices were noted to have more than tripled at key border markets near the Somalia border (FEWS 1998). This increase was at a time when virtually no livestock could be sold and exported from the area, which meant that pastoral incomes were generally inadequate to purchase badly needed food. Likewise, in Marsabit and Moyale districts of northern Kenya, the floods had disastrous effects on herders' incomes and their daily activities. Livestock diseases were rampant and their livestock deaths were in the thousands, and water structures and communication facilities such as telephone transmission lines were damaged as well (see discussion below). Food shortages led to escalating prices, and severe floodinduced erosion was reported in many parts of northern Kenya.

\section{THE CASE OF THE SOMALIA BORDERLANDS}

As defined in this article, the Somalia borderlands incorporate the Lower Jubba Region, southern Soma-

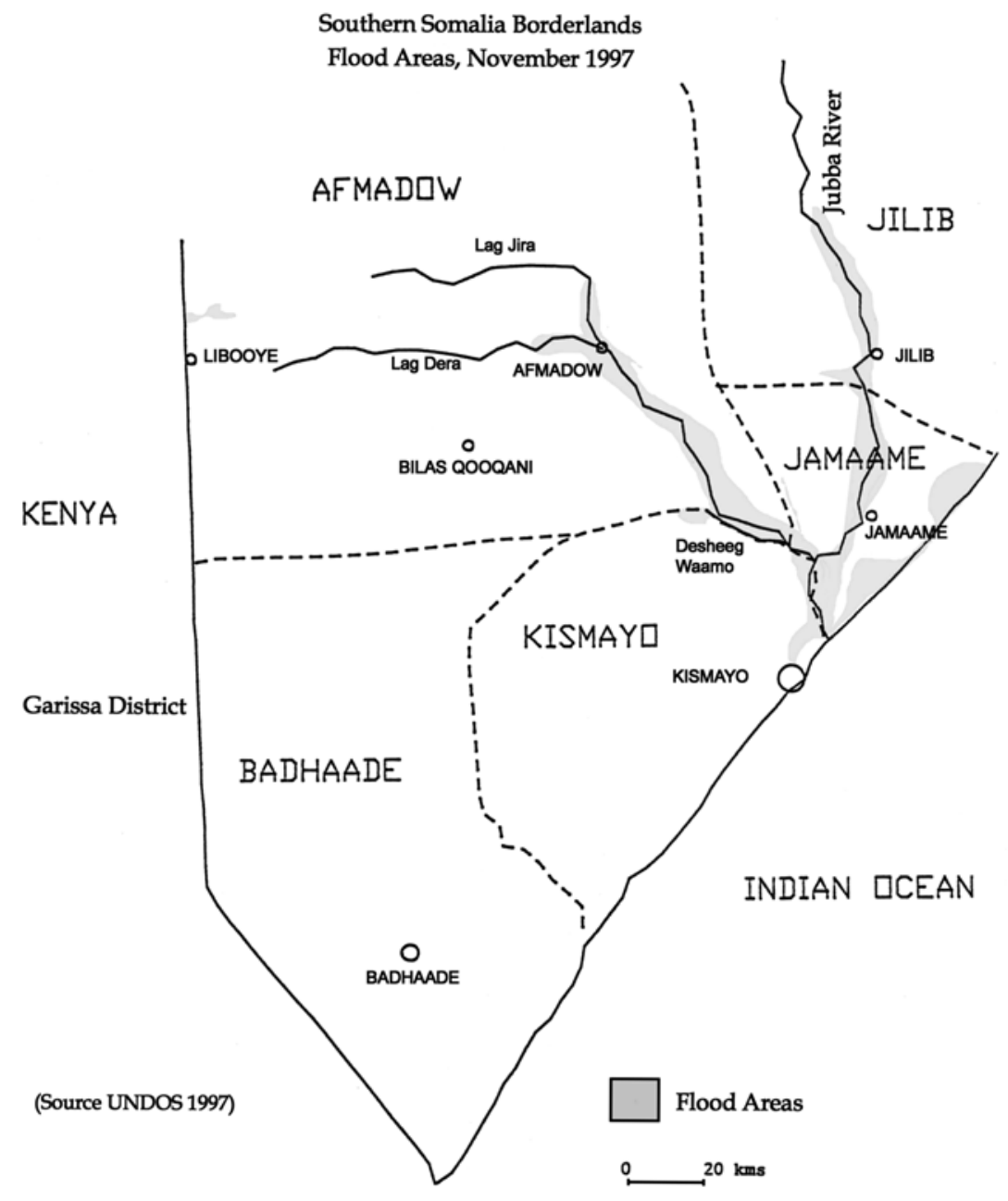

Fig. 2. Southern Somalia Borderlands: Flood Areas, November 1997

Table 1. Prices in Afmadow Market, Somalia borderlands. Based on data from the Food Security Assessment Unit (FSAU 1997, 1998). NA: not available; Shs: shillings

\begin{tabular}{|lcrr|}
\hline Commodities & $\begin{array}{c}\text { October 1997 } \\
\text { (Somali Shs) }\end{array}$ & $\begin{array}{c}\text { January 1998 } \\
\text { (Somali Shs) }\end{array}$ & $\begin{array}{c}\text { April 1998 } \\
\text { (Somali Shs) }\end{array}$ \\
\hline Local maize (kg) & 2375 & 15000 & 2000 \\
Wheat flour (kg) & 4342 & 9000 & 4000 \\
Camel milk (l) & 3250 & 45000 & 6750 \\
Local cattle (head) & 700000 & NA & NA \\
Export cattle (head) & 1118750 & Est. 7500 & Est. 400 000 \\
Exchange rate = US\$1 & 7335 & & Est. 750 000 \\
& & & Est. 7500 \\
\hline
\end{tabular}


ment in 1991 a regional governor of the Lower Jubba was based in Kismayo town. Most cultivation in the area is carried out in Jamaame and Kismayo districts. It is concentrated in the alluvial areas near the Jubba river, a relatively lush zone amidst a semi-arid plain, as well as along the coastal plain to the south of Kismayo town. While cultivation takes place in the other, more pastoral districts, it is usually a 'hit or miss' activity that obtains some success in wet years but often experiences low or no yields in the majority of years.

\subsection{Climate and seasonality}

Average rainfall in the Somalia borderlands is approximately $560 \mathrm{~mm} \mathrm{yr}^{-1}$, with the highest amounts (in excess of $700 \mathrm{~mm}$ ) concentrated in the Jubba River Valley and the lowest (less than $350 \mathrm{~mm}$ ) in the western rangelands around the Kenya-Somalia border (Hubl 1986, p. 56). The region has 4 climatic seasons: the 'long' dry season (jilaal) (January to March), the 'long' wet season ( $g u^{\prime}$ ') (April to June), the 'short' dry season (xagaa) (July to September) and the 'short' wet season (deyr) (October to December). About 30\% of annual rainfall falls during the $g u^{\prime}$ season, while the other wet season, the deyr, receives far less precipitation and even fails to occur in some years (AHT 1987). It is the most poorly defined of the 4 seasons in southern Somalia. Compared with other regions of Somalia, the Lower Jubba area is a relatively favorable rainfall area (Conze \& Labahn 1986). Water scarcity and aridity are greatest in the immediate border zone between the 2 countries and on the Kenyan side between Liboi and Garissa, a distance of about $145 \mathrm{~km}$.

It is important to recognize that localized droughts are very common in the Lower Jubba Region, forcing herders to adjust their normal grazing patterns every 4 to 5 yr. During the past 25 yr full-blown regional or national droughts have occurred about every $8 \mathrm{yr}$, while localized droughts take place about every 4 to 5 yr. A localized drought means that at least some parts of the region or nearby accessible locations have experienced at least some marked rainfall decline $(30 \%$ or more) in the long wet season, while other sites have not. A regional drought, in turn, means that the long rains ( $g u^{\prime}$ season) have almost completely failed in the entire region, while a national drought means that the long rains have failed throughout the country. During April to July 1996, the long rains of central and northern Garissa District were less than $40 \%$ of expected amounts in some areas and stopped very early in the season (Little 1996a). Fortunately, the early rains in April were quite favorable across the border in Somalia (around Lag Jira and Lag Dera) and were above average in the southern portion of Garissa District during the later part of the season (May to June). Thus, herders in the locally affected zones were able to move their animals either across the border into Somalia or southward toward the coast (the latter area being in a tsetse fly zone). During June 1996 several Kenyan herders moved their cattle as far as the Kismayo coast, where rainfall was good but armed conflict widespread. Because of their inaccessibility to former dry season grazing areas in river basins and highland zones, Kenyan herders of the central and southern Rift Valley are especially constrained during droughts (Little 1992a).

The collapse of the Somalia government and the ensuing political chaos of 1991 and 1992 added to existing risks in the region and, unfortunately, correlated with a terrible drought in southern Somalia that left communities very vulnerable and may have resulted in more than 50000 deaths in the borderlands alone, particularly in the Jubba Valley (de Waal 1997). While Garissa District, Kenya did not confront similar levels of violence, drought was widespread and rainfall amounts during the short rains of 1991 and long rains of 1992 were only 61\% (Anon. 1993a, p. 7) and $50 \%$ (Anon. 1993b, p.19) of normal levels, respectively. In short, the long rains of 1992 were an almost complete failure in the region and cattle mortality rates were as high as $60 \%$ of cattle in parts of Garissa District (Anon. 1993b, p. 12). Grain and food aid were unable to reach needy communities because of factional fighting, while drought reduced milk and meat yields and left pastoralists, particularly the poorer segments, very vulnerable.

Since the outbreak of armed conflict in southern Somalia, the grazing patterns of 1991 and 1992 seemed to have been the only ones that were seriously disrupted. During other years, herders intermittently avoided particular grazing areas because of hostilities, but nothing on the scale of those of 1991 and 1992. During these $2 \mathrm{yr}$, a time when armed clashes were widespread in the region and clan alliances were very unstable, some Somali herders moved their animals either to Kenya or to Ethiopia. Since 1993 regional grazing patterns have not been severely affected, while seasonal herd movements during 1995 to 1999 were more affected by floods and drought than by war.

\subsection{Decisions under conditions of risk and instability}

The localized droughts of 1987/88, 1992 and 1996, and the floods of 1997/98 brought similar dilemmas to Somali herders of the borderlands, even in the context of increased political instability/conflict. A model of herder decision-making can be constructed using 
(Primary Decision: Migrate/Don't migrate animals)

$\underline{1 \text { st Month into Drought }}$

Decision (D).1 Moved out of Dry Season Areas: $\underline{\text { Yes--32 }}$

No--9

D.1.1 Increased sales of livestock above normal levels (estimate)?

$\begin{array}{ll}\text { Yes--7 } & \text { Yes--2 } \\ \text { No }-25 & \text { No }-7\end{array}$

2nd Month into drought

D.2 Adjusted herding strategy by moving more than 100 kilometers to area of good rainfall?

Yes--6 Most of the herders Yes--0

No--26 moved around nearby No-- 9

boreholes and purchased

water

D.2.2 Increased sales of livestock (estimate)?

Yes--8 Yes--4

No-- $24 \quad$ No -5

D.2.4. Increased expenditures on veterinary inputs?

Yes--22

Yes--3

No--10 No-3 (not known: 3)

4th month of delayed Long Rains

D.3 Moved animals either back to Jubba valley (dry season grazing), to Kenya, or outside of region (distances of 75-100+ kilometers)?

Yes--20 Yes--0

No--10 No-6 (not known 3$)$

D.3.1 Increased sales of livestock (estimate)?

Yes--6

Yes--2

No--26

No-- 7

D.3.3. Increased purchases of fodder (estimate)?

Yes--14

Yes--3

No-- 18

No --6

Outcome six months and drought ends

Depletion of Cattle Herd (through livestock deaths or sales)

Group 1 (32 households):

Those who initially moved:

Lost: $9 \%$ of Total Herds (estimate)
Group 2 (9 households): Those who delayed movement: Lost: $14 \%$ of Total (estimate)

Fig. 3. Model of herder decisions during drought, ${ }^{a}$ Data were collected in Afmadow District, Somalia. Number of herder households $=41$

some of the formal representations of farmer choices advanced by anthropologists (Little 1996a). A similar construct can be formulated for pastoralists. We fully recognize that choices are not made independently of structural constraints and political economic factors (Little 1992a, Little in press b), but here we address local responses and decisions rather than the large structural context under which decisions are made.

Fig. 3 illustrates a decision-making sequence that highlights herder options at different points during a drought 1 mo after delayed rains, 3 mo after delayed rains and 4 mo after delayed rains (i.e. the complete failure of the long rainy season). It is based on a random sample of 41 herders of Afmadow District, south- ern Somalia, who were interviewed about herd movements, expenditures and marketing during 1987/88 (Little 1996a). While the model is based on an earlier climate event, it is suggested that the pattern generally holds for 1997/98 as well. The model shows the kinds of decisions confronting herders at each stage of a disaster, as well as their estimated responses. In some cases the numbers in the model are based on estimates derived from aggregate data (for example, purchases of such inputs as water), while in others they reflect individual responses and behavior. The model highlights 1 important decision-whether to move animals - but shows how it is closely related to choices about livestock sales, as well as purchases of 
veterinary and water inputs. It is suggested that the representation also has relevance to the El Niño event of 1997/98, since mobility (i.e. the decision to move) had a large impact on pastoral and animal welfare. Indeed, those herders who remained in river basins and low-lying towns suffered considerable losses due to floods.

Fig. 3 shows the complexity of 2 related decisions that herders face in the context of a drought: (1) Should they migrate animals back to dry season pastures or to other areas not normally used during wet seasons? and (2) Should they increase sales of livestock in anticipation that the drought will worsen? Other decisions, such as the slaughtering of animals or migration for employment, are options, but they are of limited importance in the region. The model represents a year during which there had been very little rain in either the short or long rainy seasons.

As the figure shows, the sample was divided into those herders who immediately moved out of dry season grazing areas in April (32 households or $78 \%$ of total) at the first sign of a prolonged drought and those who did not (9 households or $22 \%$ of the sample). Those who remained sedentary for most of the year in the Jubba Valley are generally poorer in livestock numbers than the general population (Little in press b), with the majority owning between 6 and 48 cattle per household as opposed to 75 cattle for the general population. The model also depicts the variability in outcome of the different decisions taken during the year. For instance, the poorer group of herders - those who did not move during the first month of failed rainexperienced a greater percentage of herd loss than the other group. Overall most herders were successful in maintaining their herd capital by migrating and by keeping their animals off a relatively depressed market. It should be noted that even during localized droughts of 8 to 9 mo duration, herder populations of Kenya can suffer losses of livestock up to $50 \%$ of total herds (Fratkin 1991, Little 1992a).

Fig. 3 shows several critical junctures where herders had to make important decisions. These included: questions regarding the timing of livestock sales; expenditure on veterinary inputs for those who stayed in the Jubba Valley (where trypanosomiasis is endemic); migration to a distant grazing zone (more than $100 \mathrm{~km}$ ); purchases of water for cattle; and expenditure on fodder. The model traces the effects of different decisions on the 2 groups of herders. As is shown, those herders who opted not to migrate long distances ended up selling more animals (at depressed prices), purchasing more veterinary medicines and losing a larger percentage of animals than those who moved. It should be noted that in both cases estimated cattle losses were not particularly high: an estimated 14\% versus about $9 \%$ of total cattle. However, reports from 1997/98 show that those herders who remained around towns and in the river valley, rather than using customary pastures in the west of the region near the Kenya border (Fig. 2), were most affected by the floods (UNIRN 1997, see footnote 2; Clark 1998).

\section{THE CASE OF MOYALE AND MARSABIT, KENYA}

The El Niño floods of 1997/98 caught the herders of Moyale and Marsabit districts, Kenya, by surprise. In the normally dry months of minuscule (less than $10 \mathrm{~mm}$ ) or non-existent precipitation, torrential rainfall occurred, turning dry desert flats into sheets of water. Local herders were confronted with floods in large parts of both districts. Initially the unusual rainfall seemed to be a blessing, since the area is very arid. However, it soon turned out to be a disaster. The damage was extensive and coping strategies of herders had to be quickly mobilized. Because the area has experienced a reduction in herder mobility as a result of increased sedentariness, many families were crowded around low-lying settlements and towns when the disaster struck. These locations were the most seriously affected by floods, especially those in Marsabit District. There was extensive damage to humans, as well as herds, property and crops. The impacts of the floods during October 1997 to January 1998 were particularly harsh because herders of northern Kenya were just recovering from the drought of 1996/97.

In Moyale and Marsabit districts, existing livestock diseases increased in intensity and severity, while uncommon diseases, such as RVD, quickly spread as a result of the unusually damp environment. Some animal diseases were not known at all to the herders; they could only describe them to one of the authors (Mahmoud). Sheep, goats and camels all were adversely affected, while bovines fared slightly better. El Niñorelated livestock diseases, such as foot rot, diarrhea and pneumonia, ravaged the entire region but mainly affected small stock herds. Reported illnesses among camels were hemorrhage septicemia, diarrohea, trypanosomiasis and pneumonia. While cattle were least affected, they too suffered from pneumonia and trypanosomiasis. Biting flies were causes of stress, especially among donkeys. High incidences of abortion were also reported, and mortality and morbidity rates were especially high among sheep, goats and camels (MALD/GTZ 1998). The mortality rate among sheep and goats was above $25 \%$ in most parts of northern Kenya, while for camels the figure varied between 10 and $45 \%$. 
Table 2 shows comparative livestock losses during the drought of 1996/97 and the El-Niño floods of 1997/98. Drought-induced mortalities were higher than El Niño-related casualties in many divisions, except for Maikona Division. In the case of the floods, those areas (Central and Laisamis divisions) with the highest percentage of settled pastoralists and minimal herd mobility were particularly affected by the prolonged rains of 1997/98. As noted earlier, sheep and goats were affected most, by both the El Niño floods and the earlier drought; these are the animals that are predominantly owned by the poorest herders. Already marginal herders who lost their animals incurred devastating financial losses. Revenue earned from cattle in the period of October 1996 to January 1997 was 870000 Kenyan pounds (1 Kenyan pound = US\$0.33 in December 1997), but dropped to 367800 pounds in the period of October 1997 to January 1998-a decrease of $58 \%$. Similarly, revenues earned from the sales of sheep and goats combined fell from 313840 Kenyan pounds to 65500 Kenyan pounds during the same period-a decrease of about $79 \%$.

Similar to the southern Somalia case, prices of essential commodities sky-rocketed during the period of the

Table 2. Estimated livestock losses during the drought of 1996/97 and the El Niño of 1997/98 in Marsabit district of northern Kenya. Adapted from MALD/GTZ (1998, p. 8)

\begin{tabular}{|c|c|c|}
\hline Division & $\begin{array}{c}\text { Mortality due } \\
\text { to drought } \\
\text { 1996/97 (\%) }\end{array}$ & $\begin{array}{l}\text { Mortality due } \\
\text { to El Niño } \\
\text { 1997/98 (\%) }\end{array}$ \\
\hline \multicolumn{3}{|l|}{ Central } \\
\hline Cattle & 25 & 1 \\
\hline Sheep & 1 & 66.7 \\
\hline Goats & 3 & 66.7 \\
\hline Camels & 0 & 0 \\
\hline \multicolumn{3}{|l|}{ Laisamis } \\
\hline Cattle & 20 & 6.1 \\
\hline Sheep & 25 & 77 \\
\hline Goats & 15 & 77 \\
\hline Camels & 2 & 28.9 \\
\hline \multicolumn{3}{|c|}{ Loiyangalani } \\
\hline Cattle & 20 & 9.7 \\
\hline Sheep & 25 & 68.3 \\
\hline Goats & 5 & 68.3 \\
\hline Camels & 1 & 16.7 \\
\hline \multicolumn{3}{|l|}{ Maikona } \\
\hline Cattle & 15 & 1 \\
\hline Sheep & 35 & 22.8 \\
\hline Goats & 30 & 22.8 \\
\hline Camels & 1 & 18 \\
\hline \multicolumn{3}{|c|}{ North Horr } \\
\hline Cattle & 10 & 12.8 \\
\hline Sheep & 35 & 48.6 \\
\hline Goats & 30 & 48.6 \\
\hline Camels & 2 & 20 \\
\hline
\end{tabular}

El Niño floods. In most locations, shortages of grains and essential foods were reported, while in other areas prices were exorbitantly high. Zones of food shortages often were located at a distance from the main Nairobi (Kenya) to Addis Ababa (Ethiopia) trunk road. This resulted in increases of about 50 to $300 \%$ in prices of maize, beans, cooking oil, sugar and tea leaves among a sample of market centers. However, at the towns of Moyale and Sololo in the far north and located along the Kenya-Ethiopia border, food shortages were avoided through imports from neighboring Ethiopia. Agricultural products, such as potatoes, rice, fruits and vegetables, are grown in abundance in southern Ethiopia and sold along the border at prices that are cheaper than elsewhere in northern Kenya. Milk, which is a key component of a herder's diet, was also in short supply due to high incidences of livestock abortions and mortalities.

Other serious impacts of the El-Niño floods were the severe damage to surface water facilities, such as pans and dams, and to wells and motorized bore holes. Destruction of communication facilities-including telephone connections-was also significant, while many of the already ill-maintained roads were converted into torrential waterways. Although soil erosion hazards are not uncommon in most parts of northern Kenya, the unexpected long showers exacerbated the condition. The erratic nature of the rainfall and the increased settlement of pastoralists in the area are among the most important factors responsible for the severe soil erosion and resource degradation that has occurred in northern Kenya during the past decade (Mahmoud 1996). Severe to very severe erosion was reported in many areas of Marsabit as a result of the El Niño floods, particularly in areas of dense human settlements and towns (MALD/GTZ 1998).

\section{CONCLUSIONS}

This article has shown that local processes and factors can greatly aggravate the effects of macro-climatic events, such as floods and droughts, and result in exaggerated claims of global climate change. How a climatic event affects a pastoral community in East Africa has as much to do with on-going social and economic processes as it does with rainfall amounts and distribution. By presenting 2 case studies from the region, we have tried to show that climate is just one of a set of significant risks that herders and communities confront, and that the local responses to these are determined by social and economic variables that cluster around strategies of mobility and resource access. As with drought situations, those groups during floods who have the capacity to be mobile generally fare better than others. 
As the analysis has shown, climatic variability and change relate closely to a number of other elements of pastoral risk. These links are especially highlighted during periods of extreme variability, such as occurred during the El Niño floods. The marketing aspect has been shown to be critical for herders who are dependent on grain purchases and livestock sales, but who were forced to retreat from commercial activities as markets collapsed and the terms of trade became increasingly unfavorable. Another element of riskpolitical instability/conflict - was also heightened after the floods, when herders attempted to recover herd losses by raiding neighboring groups and clans. In the latter half of 1998 this pattern of increased conflict was especially widespread in parts of northern Kenya, with destructive raids occurring between the Boran and Somali, and between the Turkana and Samburu (K. Smith pers. comm., Smith et al. 1999). The floods also forced considerable population dislocation and increased competition and conflict as herders moved out of their homeland areas and into agricultural zones and areas controlled by other pastoral groups. The irony is that once the floods receded in February 1998, pastures and water availability were extremely good throughout the region-ideal times for raiding livestock.

Such unusual events of incredible magnitude, such as an El Niño flood in the Northern Kenyan deserts, challenge local norms and practices. It is not an occurrence that can be planned for and, as Salzman (1999, p. 4) notes, an unexpected event can have dire consequences:

'Sometimes these events, although crushing, are known and understood ... Other events are unknown, or of a magnitude previously unknown. Sometimes all, and sometimes some people can adjust, adapt, and hang on, riding out the new circumstances, hoping for a return to the old conditions or at least to a new stability. Sometimes some people are broken-losing their jobs and property, losing their influence and standing, losing their minds or their lives — and never recovering.'

This article has shown that while some herders, with sufficient household labor and favorable access to unaffected pastures, were able to adjust to the unusual event, others suffered terrible human and animal losses. Field research in northern Kenya conducted by the PARIMA project is attempting to understand the extent to which herders have been able to recover from the floods of 1997/98, an event that tragically was followed about 18 mo later by a devastating drought (McPeak 2000).

What are the policy implications of social science research for these high-risk areas? Policies for the pastoral regions must first be concerned with allowing and, in some cases, reviving the 2 key strategies of mobility and resource access. As the article has shown, these risk management techniques allow some herders to avoid major catastrophes associated with climatic episodes. By supporting polices that do not undermine mobility and herder access to key grazing resources, it is suggested that another goal should be to strengthen pastoral production systems and assist with diversified assets and investments that supplement rather than replace pastoralism with alternative land use systems such as irrigated agriculture. Numerous studies have shown that the latter production option often increases local exposure to risk among pastoralists (Hogg 1986, 1987, Little 1996a). In some cases, this may mean allowing herders seasonal access to valuable grazing lands that were converted to national parks or agricultural schemes. The Kenya Wildlife Service, a government institution with key responsibility for wildlife and national parks, occasionally allows herders to use pastures within parks and reserves when climatic conditions are particularly severe. This kind of initiative should be applauded and efforts should be made to expand its coverage throughout northern Kenya. While social and economic losses will always be associated with droughts and floods, policies that improve herder access to seasonal pastures and markets and discourage large-scale population settlements based on food aid and relief can reduce the costs.

To conclude, a future research agenda in the pastoral areas of East Africa should look carefully at longterm, site-specific climate, animal disease and conflict data, and compare these with local perceptions of risk. How do local herders evaluate and rank different risk elements and how do these match with actual statistical occurrences of risk? In what ways do these local perceptions of climate risk vary by wealth, gender and other social variables? The work of Smith et al. (1999, 2001) and Little et al. (2001) under the PARIMA project provide a good basis for this kind of analysis, and PARIMA research will gather additional, relevant data. If climatic variability and instability have increased in recent years, what types of behavioral changes (if any) have occurred? Only through long-term, in-depth field research can these kinds of questions be answered. The recent widespread social and economic losses caused by climatic events in East Africa indicate why this type of research is urgently needed.

Acknowledgements. We wish to acknowledge write-up support from the Pastoral Risk Management in East Africa Project (PARIMA), Global Livestock Collaborative Research Support Program (GL-CRSP), Grant No. DAN-1328-G-00-0046-00. Information on the PARIMA Project can be obtained online at $<$ http://www.cnr.usu.edu/research/CRSP $>$. This article benefited from discussions with Drs A. A. Aboud of Egerton University, Chris Barrett of Cornell University, Simeon Ehui of the International Livestock Research Institute, John McPeak, Cornell University, and Kevin Smith of Utah State Univer- 
sity/GL-CRSP. The contents of the paper are the sole responsibility of the authors and none of the views expressed in the article should be attributed to the above institutions and individuals. An earlier version of this paper was presented at a session on 'Social Science Dimensions and Policy Contributions to Climate Change Research: African Perspectives', Annual Meetings of the Society for Applied Anthropology, Tucson, AZ, April 22 to 25, 1999

\section{LITERATURE CITED}

Anon. (1993a) Inter-agency drought assessment of seventeen districts in Kenya. Inter-Agency Drought Committee, Nairobi

Anon. (1993b) Inter-agency assessment of drought-affected districts in Kenya. Inter-Agency Drought Committee, Nairobi

Anon. (1998) Rift valley fever-East Africa, 1997-1998 MMWR Morb Mortal Wkly Rep 47:261-264

AHT (Agrar- Und Hydrotechnik GmbH) (1987) Masterplan for Juba Valley Development. AHT, Essen

Clark C (1998) Virus outbreak in Kenya linked to heavy rains. World Dis Weekly Plus, 9:2-3

Conze P, Labahn T (eds) (1986) Agriculture in the winds of change. epi Verlag GmbH, Saarbrucken-Schafbrucke

de Waal A (1997) Famine crimes: politics and the disaster relief industry in Africa. James Currey, Oxford

FEWS (Famine Early Warning Systems) (1998) Floods hamper food aid deliveries in Eastern Africa. FEWS Bull February 1998, FEWS, Nairobi

FSAU (Food Security Assessment Unit) (1997) Monthly marketing data. World Food Programme, Nairobi

FSAU (Food Security Assessment Unit) (1998) Monthly marketing data. World Food Programme, Nairobi

Fratkin E (1991) Surviving drought and development. Westview Press, Boulder, CO

Hogg R (1986) The new pastoralism: poverty and dependency in northern Kenya. Africa 56 (3):319-333

Hogg R (1987) Development in Kenya: drought, desertification and food scarcity. African Affairs 86:47-58

Hubl K (1986) The Nomadic Livestock Production Systems of Somalia. In: Conze P, Labahn T (eds) Agriculture in the winds of change. epi Verlag GmbH. Saarbrucken-Schafbrucke

Little PD (1992a) The elusive granary: herder, farmer, and state in northern Kenya. Cambridge University Press, Cambridge

Little PD (1992b) Traders, brokers, and market 'Crisis' in southern Somalia. Africa 62:94-124

Little PD (1994) Maidens and milk markets: the sociology of dairy marketing in southern Somalia. In: Fratkin E, Galvin $\mathrm{K}$, Roth E (eds) African pastoralist systems: the frontiers of theory and method. Lynne Reinner Publishers, Boulder, p 165-184

Little PD (1996a) The lesser of three evils: modeling pastoral resource use under conditions of drought, disease, and conflict. Final report submitted to the Small Ruminant Collaborative Research Support Program, University of California, Davis

Little PD (1996b) Cross border cattle trade and food security in the Kenya/Somalia borderlands. Institute for Development Anthropology, Binghamton
Little PD (1996c) Conflictive trade, contested identity: the effects of export markets on pastoralists of southern Somalia. Afr Stud Rev 39:25-53

Little PD (in press a) Living in risky environments: the political ecology of pastoralism in East Africa. In: Taylor $\mathrm{S}$, White G, Fratkin E (eds) African development in the 21st century. University of Rochester Press, Rochester

Little PD (in press b) The global dimensions of cross-border trade in the Somalia borderlands. In: Proceedings of the OSSREA sixth congress on globalisation, democracy, and development in africa: future prospects. Organization for Social Science Research in Eastern and Southern Africa (OSSREA), Addis Ababa

Little PD, Smith K, Cellarius BA, Coppock DL, Barrett CB (2001) Avoiding disaster: diversification and risk management among East African herders. Dev Change 32(3): $401-433$

Lovgren S (1997) Floods could bring famine. US News World Rep 123(20):53

Mahmoud HA (1996) Overgrazing, land degradation and desertification in northern Kenya: a case study of Marsabit, Kenya. MA thesis, Egerton University, Njoro, Kenya

Mahmoud HA, Little PD (2000) Climatic shocks and pastoral risk management in northern Kenya. Pract Anthropol 22: $11-14$

McCabe JT (1987) Drought and recovery: livestock dynamics among the Ngisonyoka Turkana of Kenya. Hum Ecol 15: 371-389

McCabe JT (1987) Mobility and land use among African pastoralists: old conceptual problems and new interpretations. In: Fratkin E, Galvin K, Roth E (eds). African pastoralist systems: the frontiers of theory and method. Lynne Reinner Publishers, Boulder, p 69-89

McPeak J (2000) Progress report on core field research in northern Kenya. Third annual project planning meeting, Pastoral Risk Management (PARIMA) Project. Egerton University, Njoro, Kenya, 10-11 July 2000

Menkhaus K, Marcal R (1998) Socioeconomic trends. In: Human development report, Somalia 1998. United Nations Development Office for Somalia, Nairobi, p 21-37

MALD/GTZ (Ministry of Agriculture and Livestock Development/Gesellschaft für Technische Zusammenarbeit) (1998) Survey report on the effects of El Niño, Marsabit District. MALD, Marsabit

Resource Management and Research (1984) Southern rangelands survey. National Range Agency, Mogadishu

Salzman PC (1999) The anthropology of real life: events in human experience. Waveland Press, Prospect Heights

Smith K, Barrett CB, Box PW (1999) Participatory risk mapping for targeting research and assistance: with an example from East African pastoralists. GL-CRSP Pastoral Risk Management Project Technical Report 04/99. Utah State University, Logan

Smith K, Barrett CB, Box PW (2001) Not necessarily in the same boat: heterogeneous risk assessment among East African pastoralists. J Dev Stud 37(5):1-30

Steffen P, Shirwa AH, Kayad MG, Addou SI (1998) The livestock embargo by Saudi Arabia: a report on the economic, financial and social impact on Somaliland and Somalia. FEWS, Nairobi

UNDOS (United Nations Development Office for Somalia) (1997) Maps of the Lower Jubba Region. UNDOS, Nairobi 